${ }^{1}$ School of Social Work Massey University

2 Independent Consultant, Registered Social Worker

${ }^{3}$ Aotearoa New Zealand Association of Social Workers (ANZASW)
AOTEAROA NEW ZEALAND SOCIAL WORK 32(4), 8-25.

CORRESPONDENCE TO: Polly Yeung p.yeung@massey.ac.nz

\title{
Aotearoa New Zealand social workers and their views of inclusion of animals in social work practice - A descriptive study
}

\author{
Polly Yeung ${ }^{1}$, Nicole Robertson ${ }^{2}$ and Lucy Sandford-Reed ${ }^{3}$
}

\begin{abstract}
PURPOSE: Given the benefits of the human-animal bond (HAB), animals are being used in a range of social work settings. It is important to gain a more in-depth understanding of social work practitioners' knowledge and actions in these interactions. The purpose of this study was to examine the views and knowledge of social workers in relation to the HAB in Aotearoa New Zealand.
\end{abstract}

METHODS: A survey using an online portal was administrated to qualified social workers via professional and community networks to assess their exposure, level of knowledge, support, training, and barriers to animal-human relations.

RESULTS: A total of 140 questionnaires were used for analysis. The results, similar to findings from Canada and the United States, indicate that social workers seemed to have high exposure to information about the benefits of $\mathrm{HAB}$ and understanding of the connections between animal abuse and child abuse/domestic violence. Only $68 \%$ have included animals in their social work practice. The vast majority have had no specific training in HAB. Untested or untrained animals were also reported to have been used in social work intervention practice. The lack of clear workplace policies, support and professional training in $\mathrm{HAB}$ were key barriers that inhibited the inclusion of animals in practice.

CONCLUSIONS: Lack of understanding over how to include $\mathrm{HAB}$ in practice has serious implications for social work. $\mathrm{HAB}$ continues to influence and contribute to the lives of families and individuals and social workers have a duty to develop general awareness and knowledge of the benefits to human health and wellbeing of interacting with animals.

KEYWORDS: Human-animal bonds; social work practice; animal-human relations; social justice

The human-animal bond has received growing interest in recent years (e.g., Holcombe, Strand, Nugent, \& Ng, 2016; Krause-Parello, Gulick, \& Basin, 2019; Payne et al., 2015; Payne, DeAraugo, Bennett, \& McGreevy, 2016). Bonding between animals and their human caregivers has been shown in numerous studies to improve human emotional and physical health (Barker, Rogers, Turner, Karpf, \& Suthers-Mccabe,
2003; Friedmann \& Son, 2009; Walsh, 2009; Wells, 2019). In Aotearoa New Zealand (NZ), there are at least 4.6 million companion animals and $64 \%$ of households are home to at least one companion animal (New Zealand Companion Animal Council Inc., 2016). Pets and/or companion animals are no longer considered just as a member of the family (Risley-Curtiss, 2007) and are perceived as sources of social support 
potentially reducing their caregiver's reactivity to stressful situations (Allen, Bloscovich, \& Mendes, 2002; Taylor \& Fraser, 2017). Companion animals and other animals are increasingly included in animalassisted intervention (AAI) or animalassisted therapy (AAT) as therapeutic agents to treat physical, mental and behavioural disorders for children, young people, adults and older adults, such as depression, attention deficit/hyperactivity disorder, schizophrenia, alcohol/drug addiction, trauma and chronic diseases (e.g., Fraser, Taylor, \& Signal, 2017; Gan, Hill, Yeung, Keesing, \& Netto, 2019; Gee, Mueller, \& Curl, 2017; O'Haire, Guerin, \& Kirkham, 2015; Schuck et al., 2018; Taylor, Fraser, Signal, \& Prentice, 2016; Uglow, 2019). Fine (2010) provides a succinct compilation and discussion on how AAI / AAT can offer therapeutic benefits for social work clients. The presence of animals in therapy sessions can provide a bridge into therapeutic alliances as clients may find it easier to engage with an animal before forming a trusting and working relationship with a therapist, particularly for children and people with a history of abuse and trauma (Geist, 2011; Thompson \& Gullone, 2006).

While a substantial amount of research has supported the powerful relationships between humans and companion animals and other animals from a positive perspective, companion animals are also victims of human cruelty (Arkow, 2019; Ascione, Weber, \& Wood, 1997; Gallagher, Allen, \& Jones, 2008; Holcombe et al., 2016). In 1987, cruelty to animals was added as a criterion for conduct disorder in the American Psychiatric Association's Diagnostic and Statistical Manual of Mental Disorders (Arkow, 2019). Further studies continue to confirm the growing evidence of a link between animal cruelty, child maltreatment, domestic violence, elder abuse and increased criminality with child and adult animal cruelty (Arkow, 2015; Ascione, 2005; Ascione \& Shapiro, 2009; Faver \& Strand, 2003, 2008; Flynn, 2011; Humphrey, 2002; Long et al., 2007).
Despite the prolific research correlating interpersonal violence, family violence, and child and adult animal cruelty mentioned, the benefits of cross-sector reporting continue to be hindered by the separation of animal and human welfare when it comes to intervention (Long, Long, \& Kulkarni, 2007). This disconnection ignores animal abuse being an indicator of human violence that often exists concurrently with domestic violence (Faver \& Strand, 2003) which has become a serious public health issue. In recent times, a One Welfare approach has also been established to complement the One Health approach, which focuses on the interconnections between animal welfare, human wellbeing and the environment in order to improve ways of working in a more integrated approach to achieve better animal welfare and human wellbeing globally (Pinillos et al., 2016).

Professionals in many disciplines, such as veterinarians, are now more aware of the link between animal abuse and human violence and several commentaries and reviewed articles have discussed the importance of active participation of these professionals in the cycle of violence (Benetato, Reisman, \& McCobb, 2011; Lockwood \& Arkow, 2016; Robertson, 2010). Despite scientific publications that have shown an association between animal abuse and interpersonal violence, and that animal abuse is an indicator of other forms of violence (Arkow, 2019; Flynn, 2000), studies in Australia, NZ and the USA reported that veterinarians were still reluctant to report cases of animal abuse (Donley, Patronek, \& Luke, 1999; Green \& Gullone, 2005; Williams, Dale, Clarke, \& Garrett, 2008). Moreover, despite the recognition of the existence of the link between animal abuse and family violence in veterinary medicine, only around $50 \%$ of respondents in Australia, NZ and the USA reported to have felt responsible for the human victim of violence (Green \& Gullone, 2005; Sharpe \& Wittum, 1999; Williams et al., 2008).

Although veterinarians can play a key role in detecting animal abuse and intervening 
in different types of human violence, research has also reported barriers such as the lack of training to identify animal abuse (Sharpe \& Wittum, 1999); lack of clarity in definitions of abuse, cruelty and neglect (Green \& Gullone, 2005); lack of resources to help victims (Williams et al., 2008); lack of information regarding legal rights and responsibilities toward the victims of abuse (Sharpe \& Wittum, 1999); and, lack of professional education about preventing animal abuse and human violence (Green \& Gullone, 2005).

Social work has been connected to humananimal issues in practice for over 30 years starting with Gerda Bikales (1975) who called for consideration of human-animal relationships into intervention planning. Emeritus Professor Christina Risley-Curtiss in the USA has advocated for many years for social workers to focus on humananimal interactions to address the social support role of companion animals for individuals and within family systems, the connection between animal cruelty and violence towards humans, and the therapeutic benefits of companion animals (Risley-Curtiss, 2007, 2010, 2013; RisleyCurtiss, Holley, Kodeine, 2011; Strand \& Risley-Curtiss, 2013). This has, however, historically been a challenge for social work, as Sable (1995) argued that the social work literature has given little attention to the research or theoretical explanation of the human-animal bond while other social work scholars (e.g., Arkow, 2019; Ryan, 2011) have criticised social work training and practice and the focus solely on humans, which limits a holistic response to other inhabitants in the shared eco-system (Hanrahan, 2011; Ryan, 2011). While some social work literature has advocated for social workers' responsibility to attend to the welfare of animals as part of their code of ethics and practice (O'Brien, 2003; Wolf, 2000), social work as a discipline is still struggling to solidify and professionalise the integration of animals into social work theory and practice (Fraser et al., 2017; Strand et al., 2012).
Veterinary social work (VSW), developed by Dr Elizabeth Strand from the University of Tennessee (Jackson, 2013), has pioneered the intersection between veterinary medicine and social work practice. VSW focuses on the human side of the humananimal bond through four key areas: grief and loss of an animal, compassion fatigue in the animal service fields, the link between animal abuse and human violence, and animal-assisted intervention (Holcombe et al., 2016). If animals and social work have been connected for decades, it is very likely that social workers already work with individuals who have valued relationships with animals, rather than simply as tools in a therapeutic sense (Tedeshi, Fitchett, \& Molidor, 2006) and therefore, discussions around the inclusion of animals in social work practice should not just apply to those involved with VSW but be addressed in social work education programmes and curricula (Taylor et al., 2016; Tedeschi et al., 2006). A recent research by Chalmers et al. (2020) suggested the application of zooeyia within social work as one approach to understand HAB. Zooeyia refers to positive impacts on human health from the HAB, which includes the physical, psychological, social and spiritual health benefits from the interactions with animals, particularly with companion animals (Hodgson \& Darling, 2011). Operating from the profession's ecological, strengthsbased or family-centred perspective, which requires one to look at people in social and natural environments, social work researchers, educators, and practitioners can join other disciplines to incorporate human-animal relationships into their work to enhance the professional's ability to help clients and animals (Risley-Curtiss, 2007). However, studies conducted in the USA (Risley-Curtiss, 2010; Risley-Curtiss, Rogge, Kawam, 2013) and in Canada (Chalmers et al., 2020; Hanrahan, 2013) reported significant gaps within social workers' knowledge of human-animal relations in social work practice. Interest in the human-animal bond and social 
work practice in Aotearoa NZ has been gaining momentum in recent years (e.g., Adamson \& Darroch, 2016; Darroch \& Adamson, 2016; Evans \& Gray, 2012; Evans \& Perez-y-Perez, 2013; Walker, Aimers, \& Perry, 2015, Walker \& Tumilty, 2019). The Aotearoa New Zealand Social Work Code of Ethics has also included a statement to recognise "the sentience of animals and ensure that any animal engaged as part of our social work practice is protected" (ANZASW, 2019, p. 11). Despite the importance of the bond between animals and humans being discussed in Aotearoa NZ based literature, there remains a paucity of empirical evidence on social workers' views on the inclusion of animals in their practice. Gaining an understanding of social workers' knowledge in the area of human and companion animal relationships and examining the barriers to inclusion of animals in social work practice can contribute to a better understanding of the potential benefits to social work practice and policy development.

Based on these aforementioned findings, particularly the research conducted in the USA (Risley-Curtiss, 2010) and Canada (Chalmers et al., 2020; Hanrahan, 2013), the overall purpose of this study was to examine the views and knowledge of social workers in relation to the HAB in Aotearoa New Zealand. This study had three objectives: (a) to explore the extent of exposure of social workers to and knowledge of HAB in social work practice; (b) to investigate how much social workers have included companion animals in their assessment and treatment of clients; and (c) to identify the degree of professional education and/or training received by social workers to include companion or other animals in their practice.

\section{Methods}

\section{Study population}

Between late-October 2018 and midFebruary 2019, an online survey with the aim of exploring social workers' perspectives on including animals in their practice was sent out to qualified social workers to invite them to participate. This was sent out via the Aotearoa New Zealand Association for Social Workers and other professional and community networks. A low-risk ethics notification was obtained from Massey University prior to the commencement of the research. One hundred and fifty-three responses were retrieved from the online survey portal. After data cleaning and mining, 13 responses were omitted due to significant data missing (50\% or more) from the main questions and the sociodemographic information (80\% or more). A total of 140 responses were retained for analysis. Given the online survey was circulated to many different groups and networks, we were unable to ascertain the actual response rate.

\section{Measures}

The measures used were primarily derived from previous research and are outlined in this section.

Exposure of animal-human relations. To ascertain the level of exposure about the human-other animal bond, respondents were asked to rate a total of 7-item, derived from Risley-Curtiss (2010), on a 3-point scale $(1=$ very little/none to $3=a$ lot $)$ on how much they had heard or read about human-other animal relationships. Examples of these items were "Have you heard, read, been given information on link between animal abuse and child abuse, animal abuse and domestic violence, how to help people who abuse animals?" Cronbach's alpha was at an acceptable level at 0.78 .

\section{Social work practice and animal-human} relationship. Five questions were adapted from previous research (Risley-Curtiss et al., 2013; Risley-Curtiss, Zilney, \& Hornung, 2010) to ask if social workers had come across animal abuse issues in their practice during the past five years using a 3-point scale $(1=$ very little/none to $3=$ a lot $)$. An example of the question was "Have you 
encountered clients who reported safetyrelated concerns for animals in their own homes in the past five years?" Cronbach's alpha was reported at 0.61. Participants were also asked to rate two statements regarding their views on the benefits of animal-human relationships in social work practice "inclusion of animal in practice is a beneficial adjunct to my social work practice" and "participation in human therapeutic interventions is beneficial to animal wellbeing", using a 5-point Likert scale from 1 = strongly disagree to 5 = strongly agree.

Education and training. This section included questions adapted from Risley-Curtiss (2010) and Schlote (2002). Respondents were asked whether they have received any training in including animals in social work practice (formal or informal) (yes/no); in what areas the animals were involved; reasons that would prevent them from using animals in their practice; how many years of experience in using animals in their social work practice; where the context in which animals were used in practice was; who the clients were; what service areas were the animals involved with clients; what kind of animals were used and whether they have been tested or certified. A text box was available to provide written responses regarding the type of animals used in practice.

Organisation commitment. Respondents were asked eight questions regarding the role of their organisation in relation to the use of animals in service provision. These questions were developed based on reviewing existing literature (Risley-Curtiss, 2010; Risley-Curtiss et al., 2010; Schlote, 2002; Trembath, 2014).

Socio-demographics. Participants reported their age, gender, education levels in social work, ethnicity, years of practice experience, main area of social work practice, current employment, professional affiliations and ethnicity.

Open-ended comments. The final question in the survey was an open-ended question which screened for any additional comments.

\section{Statistical analyses}

The IBM SPSS Statistical package (version 25, IBM SPSS Statistics for Windows) was used for data entry and analysis. Descriptive statistics, mainly through frequencies, was used to describe the results derived from the data. Open-ended responses were gathered to provide a context for quantitative data, and thus were not analysed using a qualitative research approach. Illustrative quotes were selected to highlight certain common and otherwise noteworthy concepts, paraphrasing is indicated by square brackets.

\section{Results}

Social workers who participated in this research were older, with $57.9 \%$ $(n=81)$ reported to be aged 50 and over and most of them were female $(93.6 \%, n=131)$. The age group and high percentage of female participants also mirrored the aging workforce and a "female-dominated profession" found in other social work studies (Lewis, 2018; Yeung, Mooney, English, \& O'Donohue, 2020). Most of the respondents identified themselves as New Zealand European/ Pākehā $(75.0 \%, n=105)$. Over 50\% $(n=75)$ of the participants had a social work qualification at Bachelor's level and 19.3\% ( $n=27)$ had a Master's level qualification. Around $43 \%(n=60)$ of the participants had 16 or more years of social work practice experience and $22.9 \%(n=32)$ had five years or less of practice experience. The main area of social work practice reported was in children and family $(51.4 \%, n=72)$, followed by adults $(19.3 \%, n=27)$. Half of the participants $(n=70)$ indicated their current employment was in statutory while $37.9 \%(n=53)$ was in non-government organisations. As to professional affiliation, $65.7 \%(n=92)$ reported to have dual affiliations with ANZASW and SWRB (Table 1). 
Table 1. Socio-demographic Descriptions of Study Participants

\begin{tabular}{|c|c|c|}
\hline Items & Number & $\%$ \\
\hline \multicolumn{3}{|l|}{ Age groups } \\
\hline 29 or less & 11 & 7.9 \\
\hline $30-39$ & 21 & 15.0 \\
\hline $40-49$ & 27 & 19.3 \\
\hline $50-59$ & 43 & 30.7 \\
\hline $60-69$ & 34 & 24.3 \\
\hline 70 and over & 4 & 2.9 \\
\hline \multicolumn{3}{|l|}{ Gender } \\
\hline Male & 9 & 6.4 \\
\hline Female & 131 & 93.6 \\
\hline \multicolumn{3}{|l|}{ Ethnicity } \\
\hline NZ European/Pakeha & 105 & 75.0 \\
\hline Maori & 15 & 10.7 \\
\hline Pacific nations & 3 & 2.1 \\
\hline Indian & 2 & 1.4 \\
\hline African & 1 & 0.7 \\
\hline Chinese & 1 & 0.7 \\
\hline Korean & 0 & 0.0 \\
\hline Other & 14 & 10.0 \\
\hline \multicolumn{3}{|l|}{ Social work qualification } \\
\hline Diploma level & 21 & 15.0 \\
\hline Bachelor level & 75 & 53.6 \\
\hline Entry Master level & 27 & 19.3 \\
\hline Other & 17 & 12.1 \\
\hline \multicolumn{3}{|l|}{ Years of social work practice experience } \\
\hline $0-5$ years & 32 & 22.9 \\
\hline $6-10$ years & 18 & 12.9 \\
\hline $11-15$ years & 29 & 20.7 \\
\hline $16-20$ years & 22 & 15.7 \\
\hline $20+$ years & 38 & 27.1 \\
\hline \multicolumn{3}{|l|}{ Current main practice area } \\
\hline Children and family & 72 & 51.4 \\
\hline Adults & 27 & 19.3 \\
\hline Older people & 14 & 10.0 \\
\hline Other & 9 & 6.4 \\
\hline \multicolumn{3}{|l|}{ Current employment } \\
\hline NGO & 53 & 37.9 \\
\hline Statutory & 70 & 50.0 \\
\hline Volunteer & 4 & 2.9 \\
\hline Self-employed & 8 & 5.7 \\
\hline Other & 4 & 2.9 \\
\hline \multicolumn{3}{|l|}{ Professional affiliation } \\
\hline Single affiliation (either ANZASW or SWRB) & 43 & 30.0 \\
\hline Dual affiliations (both ANZASW and SWRB) & 92 & 65.7 \\
\hline
\end{tabular}




\section{Exposure to information on animal-human relations}

Participants were asked how much they had heard, read or been given information about the human and animal bond. The majority of the participants responded that they had read or read some/a lot about the positive influence of companion and other animals on humans $(97.9 \%, n=137)$, followed by a link between animal abuse and child abuse $(92.9 \%, n=130)$, a link between animal abuse and domestic violence $(92.1 \%, n=129)$, how to help people who have experienced pet loss $(70.0 \%, n=$ 98), inclusion of animals in assessment and intervention $(60.0 \%, n=84)$, social workers who include animals in their practice $(42.2 \%$, $n=59)$, and how to help people who abuse animals $(30.7 \%, n=43)$ (see Table 2).

\section{Extent of animal-human relationship in social work practice}

Nearly $51 \%(n=71)$ of the participants reported that they had come across animal abuse issues in their practice during the past five years. Out of the 71 participants who had encountered animal abuse, $74.6 \%$ $(n=51)$ indicated some/a lot in relation to becoming aware of animal abuse as a rising concern in their practice with clients, followed by $64.8 \%(n=46)$ who had worked with clients who reported safety-related concerns for animals in their own homes, having worked with perpetrators of animal abuse and with one child $(49.3 \%, n=35)$ or an adolescent client who reported abusing an animal $(49.3 \%$, $n=35$ ), and worked with one adult client who reported abusing an animal (29.6\%). In addition, they were asked whether there would be any benefits of animal-human relationships in social work practice. Of the 140 participants, $94.3 \%(n=132)$ of them agreed/strongly agreed that inclusion of animal in practice such as animal-assisted intervention would benefit their social work practice, followed by $90 \%(n=126)$ reporting that they agree/strongly agree that participation in human therapeutic interventions would be beneficial to animal wellbeing (see Table 2). Over $90 \%$ of the final comments provided by participants expressed strong interest in learning more about how to include animals in social work practice or to have this service available to clients even if it was not provided by themselves. These are demonstrated by the following selected quotes from different participants:

"I am looking into post-graduate veterinary social work study and would like to see the field being introduced in NZ. This is an exciting area of growth for New Zealand social work practice."

"It is a whole new area of concern for social workers that I have only in the last year to become aware of. But nonetheless crucial to develop and be able to access some training."

"These questions [asked in the survey] have prompted me to have discussions [with my colleagues] about abuse of animals in our assessments and interventions."

"I think this area is like a gold mine that no one has really clicked [into]. I desperately want to bring animals into my social work practice; however, I don't know where/how to get training or training for my animals. I feel that so many people do not understand the value of animals in practice!! I would love to be an animal practitioner and would advocate for it every day!!"

"I am not interested in taking animals to my clients; however, I would definitely use a service that use animals for therapeutic purposes. Human can benefit greatly from the devotion and trust of animals in their lives."

\section{Education and training}

Out of the 140 participants, $67.9 \%(n=95)$ reported to have included animals in their social work practice. However, many of 
the participants $(87.9 \%, n=123)$ reported that they did not have any training (formal or informal) related to including animals in their practice and within this group $64.2 \%(n=79)$ had included animals in their social work practice. In fact, one participant expressed a different view about having a specific qualification to practice in this area:

"I don't think a person needs to be certified. This is an emotional area ... it is more important the therapist has a strong recognition of the role of animals in our world and have a strong personal experience of the value of across species relationships."

Of the 79 participants who reported having no training but included animals in their practice, $51.9 \%(n=41)$ reported to have included animals as part of their interventions, followed by $40.5 \%(n=32)$ who included animals as part of their assessment, 20.3\% $(n=16)$ who included animals in treating clients for companion animal loss and grief and 3.8\% $(n=3)$ included animals in treating clients for animal abuse.

When asked what reasons would prevent including animals in their practice, the top four reasons reported by all participants included: no clear guidelines in agency policy of allowing (or not) animals in practice $(45.7 \%, n=64)$, lack of training from my social work degree or continuing professional development $(37.9 \%, n=53)$, not being encouraged by supervisors / management team $(35.0 \%, n=49)$, and lack of standards of practice and ethical guidelines using animals in practice $(33.6 \%$, $n=47$ ) (see Table 3). Lacking clarity from agency guidelines and limited training from their social work degree and professional development were also the top barriers reported in Hanrahan's (2013) survey. It was also interesting to see some specific comments in the final comment box from participants that highlighted the gaps or challenges in including animals in a statutory social work context:
Table 2. Animal-human Relations (AHRs) and Social Work Practice

\begin{tabular}{|c|c|c|}
\hline Items & \multicolumn{2}{|c|}{ Number (\%) } \\
\hline Exposure to information on AHRs & Very little/None & Some \& A lot \\
\hline $\begin{array}{l}\text { Positive influence of companion } \\
\text { and other animals on humans }\end{array}$ & $1(0.7)$ & $137(97.9)$ \\
\hline $\begin{array}{l}\text { Link between animal abuse and } \\
\text { child abuse }\end{array}$ & $9(6.4)$ & $130(92.9)$ \\
\hline $\begin{array}{l}\text { Link between animal abuse and } \\
\text { domestic violence }\end{array}$ & $10(7.1)$ & $129(92.1)$ \\
\hline $\begin{array}{l}\text { How to help people who have } \\
\text { experienced pet loss }\end{array}$ & $38(27.1)$ & $98(70.0)$ \\
\hline $\begin{array}{l}\text { Inclusion of animals in } \\
\text { assessment and intervention }\end{array}$ & $55(39.3)$ & $84(60.0)$ \\
\hline $\begin{array}{l}\text { Social workers who include } \\
\text { animals in their practice }\end{array}$ & $78(55.7)$ & $59(42.2)$ \\
\hline $\begin{array}{l}\text { How to help people who abuse } \\
\text { animals }\end{array}$ & $95(67.9)$ & $43(30.7)$ \\
\hline $\begin{array}{l}\text { Extent of AHRs in social work } \\
\text { practice }\end{array}$ & Yes & No \\
\hline $\begin{array}{l}\text { Have come across animal abuse } \\
\text { in their practice the last five years }\end{array}$ & $71(50.7)$ & $62(44.3)$ \\
\hline $\begin{array}{l}\text { Answered "yes" to encounter } \\
\text { animal abuse }(n=71)\end{array}$ & Very little/None & Some \& A lot \\
\hline $\begin{array}{l}\text { Become aware of animal abuse } \\
\text { as a rising concern in your } \\
\text { practice with clients }\end{array}$ & $20(14.3)$ & $51(71.8)$ \\
\hline $\begin{array}{l}\text { Worked with clients who reported } \\
\text { safety-related concerns for } \\
\text { animals in their own homes }\end{array}$ & $19(26.8)$ & $46(64.8)$ \\
\hline $\begin{array}{l}\text { Worked with perpetrators of } \\
\text { animal abuse }\end{array}$ & $30(42.3)$ & $35(49.3)$ \\
\hline $\begin{array}{l}\text { Worked with one child or } \\
\text { adolescent client who reported } \\
\text { abusing an animal }\end{array}$ & $29(40.8)$ & $35(49.3)$ \\
\hline $\begin{array}{l}\text { Worked with one adult client who } \\
\text { reported abusing an animal }\end{array}$ & $42(59.2)$ & $21(29.6)$ \\
\hline $\begin{array}{l}\text { Benefits of AHRs in social work } \\
\text { practice }\end{array}$ & $\begin{array}{c}\text { Disagree \& } \\
\text { Strongly Disagree }\end{array}$ & $\begin{array}{c}\text { Agree \& } \\
\text { Strongly Agree }\end{array}$ \\
\hline $\begin{array}{l}\text { Inclusion of animals in practice is } \\
\text { a beneficial adjunct to my social } \\
\text { work practice }\end{array}$ & $7(5.0)$ & $132(94.3)$ \\
\hline $\begin{array}{l}\text { Participation in human therapeutic } \\
\text { interventions is beneficial to } \\
\text { animal wellbeing }\end{array}$ & $12(8.5)$ & $126(90.0)$ \\
\hline
\end{tabular}

"I think [including animals in practice] is a great idea. Unfortunately, in a statutory environment it often would not be the focus, but I can see the benefit of it for 
Table 3. Education and Training in AHRs

\begin{tabular}{|c|c|c|}
\hline \multirow[t]{2}{*}{ Items } & \multicolumn{2}{|c|}{ Number (\%) } \\
\hline & Yes & No \\
\hline Inclusion of animals in practice & $95(67.9)$ & $45(32.1)$ \\
\hline \multicolumn{3}{|l|}{ Training } \\
\hline $\begin{array}{l}\text { Receive any training (formal or } \\
\text { informal) related to including } \\
\text { animals in practice }\end{array}$ & $15(10.7)$ & $123(87.9)$ \\
\hline $\begin{array}{l}\text { No training but include animals in } \\
\text { their practice }(\mathrm{N}=123)\end{array}$ & $79(64.2)$ & $44(35.8)$ \\
\hline \multicolumn{3}{|l|}{$\begin{array}{l}\text { Inclusion of animals (no training } \\
\text { received) in which areas }(n=79)\end{array}$} \\
\hline Part of interventions & $41(51.9)$ & $38(48.1)$ \\
\hline Part of assessment & $32(40.5)$ & $47(59.5)$ \\
\hline $\begin{array}{l}\text { Treating clients for companion } \\
\text { animals' loss and grief }\end{array}$ & $16(20.3)$ & $63(79.7)$ \\
\hline Treating clients for animal abuse & $3(3.8)$ & $76(96.2)$ \\
\hline \multicolumn{3}{|l|}{$\begin{array}{l}\text { Reasons preventing them to include } \\
\text { animals in practice* }\end{array}$} \\
\hline $\begin{array}{l}\text { No clear guidelines in agency } \\
\text { policy of allowing (or not) animals in } \\
\text { practice }\end{array}$ & $64(45.7)$ & $75(53.6)$ \\
\hline $\begin{array}{l}\text { Lack of training from my social work } \\
\text { degree or continuing professional } \\
\text { development }\end{array}$ & $53(37.9)$ & $86(61.4)$ \\
\hline $\begin{array}{l}\text { Not being encouraged by } \\
\text { supervisors/management team }\end{array}$ & $49(35.0)$ & $90(64.3)$ \\
\hline $\begin{array}{l}\text { Lack of standards of practice and } \\
\text { ethical guidelines using animals in } \\
\text { practice }\end{array}$ & $47(33.6)$ & $92(65.7)$ \\
\hline Have not thought of doing so & $25(17.9)$ & $115(82.1)$ \\
\hline $\begin{array}{l}\text { Fear of liability (animal hurting a } \\
\text { client or clients' fear) }\end{array}$ & $19(13.6)$ & $120(85.7)$ \\
\hline Against agency policy & $15(10.7)$ & $124(88.6)$ \\
\hline Clients allergies & $8(5.7)$ & $130(92.9)$ \\
\hline Fearful to animals myself & $5(3.6)$ & $133(95.0)$ \\
\hline $\begin{array}{l}\text { Do not see the value of using } \\
\text { animals in my practice }\end{array}$ & $4(2.9)$ & $135(96.4)$ \\
\hline
\end{tabular}

\section{*Multiple answers allowed}

long term intervention with children/ young person in care."

"I am very interested in statutory social work to ensure there are robust and clear processes in place to always have animals interlinked to assessment, investigation and intervention."

"I would like to see more training for statutory social workers to recognise signs of animal violence / cruelty and its links to child abuse/family violence. I would like to see animal welfare factor into the practice framework for Oranga Tamariki social workers."

Table 4 provides information on the context of where and how animal-human relationships (AHRs) have taken place for 95 participants who reported to have used animals in their social work practice. Just over $40 \%(n=39)$ indicated that they had five years or less of experience in using animals in their social work practice. The main practice context where animals were used was at an agency or organisation $(28.4 \%, n=27)$, followed by private practice or self-employment $(12.6 \%, n=12)$. Participants typically used animals in social work practice for children (aged 0-12 years) $(35.8 \%, n=34)$, followed by adolescents (aged 13-19 years) $(32.6 \%, n=31)$, and adults $(25.3 \%, n=24)$. Mental health (e.g., depression, anxiety) was the main service area where animals were used in therapeutic practice $(53.7 \%, n=51)$, followed by grief and loss $(45.3 \%, n=43)$ and trauma $(43.2 \%, n=41)$. A total of $24 \%(n=23)$ reported to have used their own animals in their practice and, among them, only nine $(39.1 \%)$ have had their animals tested or trained for therapeutic work. Dogs $(67.4 \%, n=64)$ were reported to be the most common species of animal used when providing therapies to clients. Quite a few participants provided reasons for why they included untested or untrained animals in their practice, which mainly derived from their own personal perceptions and subjective assessment on their own animal's temperament:

"I had a small dog that would read people's stress and in doing so would quietly move to be next to them for comfort."

"I have used two of my own dogs, both of whom have been brought up in an 
office setting with lots of interaction with a wide range of people."

"My dog is naturally attuned to children and with parental consent has helped a child who was fearful of dogs."

"[My] own pet that I take to rest home to visit my own family member and then it morphed into therapy with other residents as they asked to see/ pat my dog. My dog is used to be around older people. She is small and non-threatening which I think is why the residents asked me to work with them."

"The animals I have used with clients are chosen for their calm but fun nature and ability to sit quietly with the client."

\section{Commitment from organisations}

Among the 140 participants, the vast majority indicated that their current organisation did not provide training that included skills for workers to recognise and assess for animal abuse $(90.7 \%, n=127)$, followed by assessing the types of relationships that families and / or households have with their animals $(80.0 \%, n=112)$ and whether the families and / or households have animals $(67.9 \%, n=67.9)$. Even when professional development and training were available from the organisations, over $90 \%(n=131)$ of the participants reported that the training was not about the benefits of using animals in practice. Around $70 \%$ responded that their current organisation did not include animal abuse in safety assessment and risk assessment protocols $(n=106)$ and service provision to clients $(n=102)$. Less than $40 \%$ $(n=53)$ of the responses indicated there were policies or training to interagency sharing or collaboration of animal abuse and human violence. Only half of the responses $(n=70)$ indicated that their current organisation would encourage them to document and take action when/if animal abuse was identified in their social work practice (see Table 5). These results are similar to the ones reported in
Table 4. Context of Where and How AHRs Take Place $(n=95)$

\begin{tabular}{|c|c|c|}
\hline Items & \multicolumn{2}{|c|}{ Number $(\%)$} \\
\hline Practice contexts where animals were used & Yes & No \\
\hline At an agency/organisation & $27(28.4)$ & $68(71.6)$ \\
\hline In private practice/self-employed & $12(12.6)$ & $83(87.4)$ \\
\hline $\begin{array}{l}\text { At a residential treatment centre (e.g., } \\
\text { nursing homes) }\end{array}$ & $11(11.6)$ & $84(88.4)$ \\
\hline In a hospital & $9(9.5)$ & $86(90.5)$ \\
\hline In a school & $7(7.4)$ & $88(92.6)$ \\
\hline \multicolumn{3}{|l|}{ Client groups } \\
\hline Children (aged 0-12 years) & $34(35.8)$ & $61(64.2)$ \\
\hline Adolescents (aged 13-19 years) & $31(32.6)$ & $64(67.4)$ \\
\hline Adults & $24(25.3)$ & $71(74.7)$ \\
\hline Young adults (aged $20-25$ years) & $11(11.6)$ & $84(88.4)$ \\
\hline Older adults & $17(17.9)$ & $78(82.1)$ \\
\hline Couples/families & $9(9.5)$ & $86(90.5)$ \\
\hline \multicolumn{3}{|l|}{ Service areas where animals were used } \\
\hline Mental health (e.g., depression, anxiety) & $51(53.7)$ & $44(46.3)$ \\
\hline Grief and loss & $43(45.3)$ & $52(54.7)$ \\
\hline Trauma & $41(43.2)$ & $54(56.8)$ \\
\hline Personal growth and self-awareness & $27(28.4)$ & $68(71.6)$ \\
\hline Self-regulation & $27(28.4)$ & $68(71.6)$ \\
\hline Interpersonal relationships & $27(28.4)$ & $68(71.6)$ \\
\hline Group development and team building & $6(6.3)$ & $89(93.7)$ \\
\hline Use your own animals in your practice? & $23(24.2)$ & $72(75.8)$ \\
\hline $\begin{array}{l}\text { If yes, have your animals been tested or } \\
\text { trained? }(n=23)\end{array}$ & $9(39.1)$ & $14(60.8)$ \\
\hline \multicolumn{3}{|l|}{ Species of animal used in therapy } \\
\hline Dogs & $64(67.4)$ & $31(32.6)$ \\
\hline Cats & $22(23.2)$ & $73(76.8)$ \\
\hline Horses & $21(22.1)$ & $74(77.9)$ \\
\hline Farm animals & $5(5.3)$ & $90(94.7)$ \\
\hline Domesticated birds & $4(4.2)$ & $91(95.8)$ \\
\hline Rabbits & $3(3.2)$ & $92(96.8)$ \\
\hline
\end{tabular}

the USA (Risley-Curtiss, 2010) and Canada (Hanrahan, 2013). Many of the participants indicated that they would want to see more support and training provided to include animals in social work practice:

"Can we have more PD [professional development] to help us begin using this therapy in our practice please?" 
Table 5. Commitment from Organisations

\begin{tabular}{|c|c|c|}
\hline Items & \multicolumn{2}{|c|}{ Number (\%) } \\
\hline $\begin{array}{l}\text { Does your organisation provide training } \\
\text { to ask the followings in your social work } \\
\text { practice? }\end{array}$ & Yes & No \\
\hline $\begin{array}{l}\text { Ways for workers to recognise and assess } \\
\text { for animal abuse }\end{array}$ & $12(8.6)$ & $127(90.7)$ \\
\hline $\begin{array}{l}\text { Assessing for the types of relationships that } \\
\text { families and/or households have with their } \\
\text { animals }\end{array}$ & 27 (19.3) & $112(80.0)$ \\
\hline $\begin{array}{l}\text { Whether the families and/or households } \\
\text { have animals }\end{array}$ & $44(31.4)$ & 95 (67.9) \\
\hline \multicolumn{3}{|l|}{$\begin{array}{l}\text { Does your organisation provide the following } \\
\text { trainings? }\end{array}$} \\
\hline $\begin{array}{l}\text { Training related to the benefits of including } \\
\text { animals, such as AAI, in practice }\end{array}$ & $9(6.4)$ & 131 (93.6) \\
\hline $\begin{array}{l}\text { Include animal abuse in safety assessment } \\
\text { and risk assessment protocols }\end{array}$ & $34(24.3)$ & $106(75.7)$ \\
\hline $\begin{array}{l}\text { Inclusion of animals, such as animal- } \\
\text { assisted intervention (AAI), in services } \\
\text { provide to your clients }\end{array}$ & $38(27.1)$ & $102(72.8)$ \\
\hline $\begin{array}{l}\text { Policies or training related to interagency } \\
\text { sharing or collaboration of animal and child/ } \\
\text { domestic/family/elder abuse }\end{array}$ & 53 (37.9) & $86(61.4)$ \\
\hline $\begin{array}{l}\text { Encourage you to document and take action } \\
\text { when/if animal abuse is identified }\end{array}$ & $70(50.0)$ & $70(50.0)$ \\
\hline
\end{tabular}

"I have not formally used animals in my practice, but I have worked with people who have service dogs. If I had the opportunity, I would most definitely use animals in my work more often, but it is not encouraged except under very special circumstances."

"I would love the opportunity to train in this area as I am very committed to animals in therapy and healing. I believe the link between animal abuse and family harm is a very strong link that cannot be denied."

Interestingly, only one participant wrote about the importance of embedding animal welfare in using animals in social work practice: "overall to me animals are the same as humans and deserve the same right[s]. If we do not do that, then there is a problem."

\section{Discussion}

This study investigated the knowledge, experiences and perceptions of social workers in relation to including animals in their practice. To our knowledge, this is the first study conducted in Aotearoa New Zealand regarding social workers' views in the area of $\mathrm{HAB}$, its potential contribution and implementation in social work practice and the challenges faced by practitioners. The current results provide a preliminary profile of what social work participants know about how social work issues are informed by $\mathrm{HAB}$, and how such understandings are operationalised in practice. The first key finding of this study indicated that most of the participants have been exposed to fairly high level of information on AHRs, particularly in relation to the positive influence of animals on humans and the links between animal abuse and child abuse/domestic violence. However, being exposed to HAB does not necessarily translate into actual practice or being able to practise competently. The current study's rates of exposure to information on animals and AHRs are similar to the USA (RisleyCurtiss, 2010) and Canadian (Chalmers et al., 2020; Hanrahan, 2013) studies, but our cohort scored lower in exposure to hearing about including animals in social work practice and how to help people who abuse animals. While more than $90 \%$ of the participants reported that the inclusion of animals in practice was beneficial to social work practice, only a small number have received either formal or informal training. Such results align with Risley-Curtiss's (2010) findings that, of those who included animals in their practice, a significant number were practising without relevant training and education. Even if they claimed to use animals in their practice, many of them in the current study (between 48 and $60 \%$ ) did not include animals as part of their interventions and assessment, and showed discrepancies in practice, consistent with previous research outcomes (Chalmers et al., 2020; Hanrahan, 2013; Risley-Curtiss, 2010). 
Participants in this study reported a high level of exposure on how to help people who have experienced pet loss but, interestingly, only $20 \%$ of social workers have included animals in treating clients for pet loss and grief which was different to previous research findings of 57.7\% (Risley-Curtiss, 2010). Risley-Curtiss argued that social workers in her study may prefer the treatment of loss and grief due to its more ubiquitous nature and requires less specialised aspects of treatment than abuse occurring in HAB. The low uptake by social work participants in the current study in involving animals to treat clients for pet loss and grief could be impacted upon by the limited inquiries about pets when gathering family / personal background information. Donohue (2005) recommended that social workers should include a few standard questions in assessments including whether a person owns a pet, how the pet is integrated into the daily life of the individual or family, and if there have been any recent pet losses, in order to provide appropriate interventions.

The second key finding highlighted the importance of having competence in AAI/ AAT. Participants' limited integration of animals as part of interventions and assessment, and the low involvement in treating clients for animal abuse $(3 \%)$ in social work practice are likely to be related to the lack of qualification in this field, lack of education and training from social work courses, professional development and organisational support (Hanrahan, 2013; Risley-Curtiss, 2010; Wenocur, Cabral, $\&$ Karlovits, 2018). Social workers are ethically bound to "exercise due care for the interests and safety of those for whom we have professional responsibility, by limiting professional practice to areas of demonstrated competence" (ANZASW, 2019, p. 11). This should also apply to relationships with non-human animals. The importance of recognising the role of animals in social work practice and our obligations to protect them can be seen in the 2019 Social Work Code of Ethics in ANZASW, which provides a formal acknowledgement of animals by the social work profession. Given the rising popularity of the benefits of AAI/AAT and pet ownership, social workers will inevitably become more involved in non-human-animal interactions. This was further explained by Fine's (2015) argument that, when social workers involve non-human animals in their work, they should be subject to the ethical and moral responsibilities of understanding the important mechanisms of the inclusion of animals in practice and ensure safety for both the client and animal. Our study provided an interesting but also concerning phenomenon of competence in AAI / AAT. Out of the 95 participants who reported that they have included animals in their practice, 23 of them reported using their animals but only nine of them indicated that they have had their animals tested or trained. Chandler (2005) argued that therapy animals, even if they belong to the therapists themselves, play a different role in an unfamiliar environment, such as school, nursing homes or hospital, and they may be required to interact with clients or people they do not know on physical and emotional levels. Research has strongly suggested that professionals need to have competence in including animals in practice as it is their duty of competence to determine the appropriate role for their animals to work with potential clients (Howie, 2015; VanFleet \& Faa-Thompson, 2017). As social work aims to be a justiceoriented profession, it is also important for social workers to promote sensitivity to, and knowledge about, social and cultural diversity. Wenocur et al. (2018) have claimed that social workers should not presume or pressure clients to conform to their own conceptualisation of HAB. Individual and cultural differences may dictate how clients respond to the suggestion of using animals in therapeutic contexts or how they view the purpose of their own animals / pets in their daily living situations (Risley-Curtiss, Holley, Wolf, 2006). Not all clients will have pets or want to participate in AAI / AAT. In fact, some may have allergies or fear of the animals for personal, social and/or cultural reasons. Social workers are encouraged to maintain openness to diverse social and cultural perceptions of using animals 
for assessment and intervention and find opportunities to engage in open discussion with clients (Hyers, 2015).

The lack of competence in implementing AAI / AAT and the inclusion of animals in social work has been criticised by social work scholars for disregarding humancompanion-animal relationships to enhance our best ability to help our clients (RisleyCurtiss, 2010; Taylor et al., 2016; Walker et al., 2015). The current research provides an indicative trend that there is a push to challenge anthropocentrism (privileging of human interests over animals), which can be seen from the respondents' motivations to include animals in practice and a willingness to pursue this. However, it is important to emphasise that more work is still needed to close the gap between people being interested to learn more and putting knowledge into practice ethically and competently. Within Western culture, consideration of the interests of animals may have become more prevalent but ultimately animals are still considered inferior to humans (Garner, 2003). An anti-oppressive approach has been suggested as a useful lens to examine how the involvement of animals in social work practice can be considered in a just way (Legge \& Robinson, 2017) as the integration of animals can continue to benefit the many fields of practice where social work has already played a significant role in addressing marginalisation and inequality. This can be seen in addressing sexism and oppression (Adam \& Donovan, 1995) and, as Fraser and Taylor (2016) have argued, the notion of intersectionality must include human-animal interactions to address the unequal distribution of power that further oppress both animals and women.

Aside from identifying animal abuse as an important risk factor of harm and risk to humans, further focus on the animals themselves as victims is vital in challenging the traditional status quo (Solot, 1997). By addressing animal and domestic/family violence together, there is a potential to find new ways to challenge other, related, forms of oppression and move closer towards social justice for animals and humans (Potts, 2010). To achieve this, examining organisational policies to create spaces in which humans and other animals can work together is a crucial step. Despite the growing literature and research evidence to report the link between animal abuse, domestic/family violence and child cruelty over the past two decades, it is discouraging to note the high percentage of participants reporting the lack of policies, guidelines and training provided by organisations in AAI/ AAT, including animal abuse in assessment, and cross-report/interagency collaboration. These findings raise intriguing questions regarding whether those participants who did report having experiences in dealing with animal abuse and family violence were by chance rather than through formal intake or assessment protocols. Research has indicated that people who experienced family or animal violence were more likely to be exposed to at least one additional type of abuse (DeGue \& DiLillo, 2009). Therefore, the process of cross-reporting may help to identify an initial reliable red flag for the presence of child maltreatment, domestic violence and animal abuse. The low level of training or policies relating to crossreporting or interagency sharing reported in the current study is probably attributed to the limited resources available to social welfare agencies and a lack of legislation. Currently in Aotearoa New Zealand, there is a memorandum of understanding (MOU) between SPCA New Zealand and the Ministry for Children, Oranga Tamariki, to encourage cross-reporting of child and animal abuse between agencies, but it is not mandated (SPCA, n.d.).

Risley-Curtiss et al. (2010) identified similar issues in their study of the limited integration of questions about animal abuse in assessment protocols for child protective services. They argued that most assessment protocols used standardised instruments which tended to be developed by outside agencies or personnel who may not have the necessary knowledge in this field and where 
these instruments were too difficult and costly to change once they were developed. Social service organisations need to consider the importance of the relationships that people have with their companion/pet animals when accessing services, particularly for those involved with housing or family violence in which not only people experience oppression and marginalisation but also the welfare and safety of animals is involved (Legge, 2016). The lack of policy and practice was highlighted in the research conducted in 2011 by SPCA New Zealand in Aotearoa New Zealand, which identified that women wanted to take their animals with them during violent relationships but faced several structural barriers. These included a lack of support agencies, such as refuge, and crisis/rental accommodation, that allowed animals (Roguski, 2012). The debate about including animals in practice by social work practitioners has received substantial attention since the work published by Risley-Curtiss in 2010 and 10 years later, perceptions and knowledge of its importance and applications remain a challenging area to develop. Consequently, the findings of the current research further highlight a growing obligation for social work educators and researchers to engage in more critical discussion around the consideration of how our professional discipline responds to non-human animals encountered during the course of practice.

In recent times, more skills emphasis has been given to the need to ensure that animal welfare, rights and wellbeing are protected and their connections with, or benefits to, human beings is understood (Taylor et al., 2016; Walker \& Tumilty, 2019). In fact, concerns about animal welfare are not exclusive in the therapeutic context but also in research. A study by $\mathrm{Ng}$ and colleagues (2018) reported that AAI/AAT publications seldom report how animals were used or the possible adverse outcomes for the animals, along with limited discussion on training, certification and veterinary care of the animals involved. While extended guidelines on how to treat therapy animals have been published by the International Association of Human-Animal Interaction Organisations (IAHAIO) (Glenk, 2017), precise criteria to ensure welfare among therapy animals are still missing due to the diverse spectrum of types of AAI/AAT; hence, establishing a set of universal guidelines remains underdeveloped ( $\mathrm{Ng}$, Albright, Fine, \& Peralta, 2015). Although social workers in the current study may be enthusiastic and feel ready to include animals in their practice, without proper qualifications in this field and accompanied by uncertified and unqualified animals, could lead to detrimental effects on the welfare of both clients and animals. Existing research has reported that, even for certified animal handlers, the familiarity with dogs' behavioural cues such as spotting signs of discomfort varied substantially between them (Hatch, 2007). This means, even if professionals like social workers have acquired the appropriate qualifications to implement AAI/AAT, they must be aware of their animal's temperament and the settings in which the animal might best meet the needs of clients (Adamson \& Darroch, 2016; Wenocur et al., 2018). Lack of knowledge and uncritical anthropomorphism to detect an animal's feelings and personality, particularly when they are anxious and stressed, can cause serious harm to people (McBride \& Montgomery, 2018). Therefore, it is central for social workers to reflect on their positions in relation to offering AAI/ AAT. If they present themselves or claim to be specialists with an expertise to include animals in social work practice, they should legally be held to the standards of a social worker specialising in this area of practice (Wenocur et al., 2018).

\section{Conclusion}

There are several limitations in this study to consider when interpreting the results of these findings. First, this was a crosssectional study and its results cannot be generalised to other social workers. Given the surveys were circulated to social workers from different professional networks, it was impossible to estimate the exact response 
rate. The focus of this research included social workers who have had experience working with family / whānau and animals and were interested in the area of HAB or included animals in social work practice. This may have excluded social workers from other fields of practice who have used animals in their social work practice or those that are unfamiliar in this area of work but who could see the potential benefits for their clients to contribute further to this topic. In addition, the rate of familiarity with $\mathrm{HAB}$ reported may have been positive skewed by social work participants answering the survey due to their own interest. Future research should focus on a national study to canvass Aotearoa New Zealand social workers' views on $\mathrm{HAB}$ and including animals in social work practice. Secondly, although the study did not set out to look at ethnic diversity among social workers in relation to $\mathrm{HAB}$, only $11 \%$ of the participants identified as Māori. As professionals in a discipline that recognises Te Tiriti o Waitangi as the basis of our governance (ANZASW, 2019), understanding the concept of kinship between human and other animals in indigenous cultures can enrich social workers' interactions with the people who use their services. Legge and Robinson (2017) argued that social work cannot overlook the impact of colonisation and its ongoing impact for indigenous communities and the use of animals in their traditional practice and the significance of this. If social workers are to support Indigenous peoples to enhance their own wellbeing, we must understand how that wellbeing is intimately connected with humans, animals and the natural world within the context of physical and spiritual dimensions (Watene, 2016).

Overall, the findings of the current study are quite similar to those of the USA (RisleyCurtiss, 2010) and Canadian (Chalmers et al., 2020; Hanrahan, 2013) surveys. Despite some notable contributions of the importance of $\mathrm{HAB}$ articulated in social work literature in the past decade, the current results continue to illustrate the lack of integration of animals in social work practice from social workers themselves and also organisational support and guidance, which reflects the concern raised by Ryan (2011) that social work practice seems to assume human distinctiveness from other animals. This study also reveals the lack of training and competence among social workers in $\mathrm{HAB}$ and the use of untrained and uncertified animals to provide interventions or to be included when working with clients. As articulated by Taylor and colleagues (2016), future social work does not need to exclude animals or be anthropocentric, but to integrate them into practice that can be beneficial to clients with diverse backgrounds, as well as to social workers themselves (Evans \& Gray, 2012).

Not all clients want to participate in $\mathrm{HAB}$ or consider it as an appropriate intervention or support for them, just as not every social worker would want to include animals in their practice. However, if social work is grounded in the core values of "meeting individual, group, national and international changing needs and aspirations; and the achievement of social justice for all" (ANZASW, 2019, p. 9), social workers need to have a responsibility to honour the non-human animal relationships in an ethically informed manner, rather than these being based on individual curiosity and interests.

Accepted 31 August 2020

Published 15 December 2020

\section{Funding Acknowledgements}

No funding attached.

\section{Conflict of interests}

The authors declare that there is no conflict of interest.

\section{Ethics approval}

Low-risk notification was obtained from Massey University. 


\section{References}

Adams, C. J., \& Donovan, J. (1995). Animals and women: Feminists theoretical explorations. Duke University Press.

Adamson, C., \& Darroch, J. (2016). When Ida came to class: The inclusion of animals in the social work curriculum. Advances in Social Work \& Welfare Education, 18(2), 39-51.

Allen, K., Blascovich, J., \& Mendes, W. B. (2002). Cardiovascular reactivity and the presence of pets, friends, and spouses: The truth about cats and dogs. Psychosomatic Medicine, 64, 727-739.

Aotearoa New Zealand Association of Social Workers. (2019). Code of ethics 2019. Retrieved from https:// anzasw.nz/wp-content/uploads/ANZASW-Code-ofEthics-Final-1-Aug-2019.pdf

Arkow, P. (2015). A link across the lifespan: Animal abuse as a marker for traumatic experiences in child abuse, domestic violence and elder abuse. Academy on Violence and Abuse. Retrieved from https:// avahealthorg.presencehost.net/file_download/inline/ b64aff80-5461-4d9b-9cdc-cf9b47f30174

Arkow, P. (2019). The "dark side" of the human-animal bond. In L. Kogan and C. Blazina (Eds), Clinician's guide to treating animal companion issues: Addressing humananimal interaction (pp. 319-346). Academic Press.

Ascione, F.R. (2005). Children and animals: Exploring the roots of kindness and cruelty. Purdue University Press.

Ascione, F. R., \& Shapiro, K. (2009). People and animals, kindness and cruelty: Research directions and policy implications. Journal of Social Issues, 65(3), 569-587.

Ascione, F. R., Weber, C. V., \& Wood, D. (1997). The abuse of animals and domestic violence: A national survey of shelter for women who are battered. Society \& Animals, 5(3), 205-218.

Barker, S. B., Rogers, C. S., Turner, J. W., Karpf, A. S., \& Suthers-Mccabe, H. M. (2003). Benefits of interacting with companion animals: A bibliography of articles published in refereed journals during the past five years. The American Behavioral Scientist, 47(1), 94-97.

Benetato, M. A., Reisman, R., \& McCobb, E. (2011). The veterinarian's role in animal cruelty cases. Journal of American Veterinary Medical Association, 238, 31-34.

Bikales, G. (1975). The dog as "significant other." Social Work, 20(2), 150-152.

Chalmers, D., Dell, C., Rohr, B., Dixon, J., Dowling, T., \& Hanrahan, C. (2020). Recognizing animals as an important part of helping: A survey exploring knowledge and practice among Canadian social workers. Critical Social Work, 21(1), 2-29.

Chandler, C. K. (2005). Animal assisted therapy in counselling. Routledge.

Darroch, J., \& Adamson, C. (2016). Companion animals and disasters: The role of human services organisations. Aotearoa New Zealand Social Work, 28(4), 100-108.

DeGue, S., \& DiLillo, D. (2009). Is animal cruelty a "red flag" for family violence? Investigating co-occurring violence toward children, partners, and pets. Journal of Interpersonal Violence, 24(6), 1036-1056.

Donohue, K. (2005). Pet loss: Implications for social work practice. Social Work, 50(2), 187-190.
Donley, L., Patronek, G. J., \& Luke, C. (1999). Animal abuse in Massachusetts: A summary of case reports at the MSPCA and attitudes of Massachusetts veterinarians. Journal of Applied Animal Welfare Science, 2, 59-73.

Evans, N., \& Gray, C. (2012). The practice and ethics of animal-assisted therapy with children and young people: Is it enough that we don't eat our co-workers? The British Journal of Social Work, 42, 600-617.

Evans, N., \& Perez-y-Perez, M. (2013). Will Marley come home? An exploration of the impacts of the Canterbury earthquakes on people's relationships with their companion animals. Aotearoa New Zealand Social Work, 25(2), 7-17.

Faver, C. A., \& Strand, E. B. (2003). Domestic violence and animal cruelty. Untangling the web of abuse. Journal of Social Work Education, 39(2), 237-253.

Faver, C. A., \& Strand, E. B. (2008). Unleashing compassion: Social work and animal abuse. In F.R. Ascione (Ed.), International handbook of animal abuse and cruelty: Theory, research, and application (pp. 175-199). Purdue University Press.

Fine, A. (2010). Handbook on animal-assisted therapy: Theoretical foundations and guidelines for practice. Academic Press.

Fine, A. H. (2015). Handbook on animal-assisted therapy (4th ed.). California State Polytechnic University.

Flynn, C. P. (2000). Why family professionals can no longer ignore violence toward animals. Family Relations, 49, 87-95.

Flynn, C. P. (2011). Examining the links between animal abuse and human violence. Crime, Law \& Social Change, 55, 453-468.

Fraser, H., \& Taylor, N. (2016). Neoliberalisation, universities and the public intellectual: Species, gender and class and the production of knowledge. Palgrave Macmillan.

Fraser, H., Taylor, N., \& Signal, T. (2017). Young people empathising with other animals: Reflections on an Australian RSPCA humane education programme. Aotearoa New Zealand Social Work, 29(3), 5-16.

Friedmann, E., \& Son, H. (2009). The human-companion animal bond: How humans benefit. Veterinary Clinics: Small Animal Practice, 39, 293-326.

Gallagher, B., Allen, M., \& Jones, B. (1998). Animal abuse and intimate partner violence: Researching the link and its significance in Ireland - A veterinary perspective. Irish Veterinary Journal, 61(10), 658-667.

Gan, G. H., Hill, A., Yeung, P., Keesing, S., \& Netto, J. A. (2019). Pet ownership and its influence on mental health in older adults. Aging \& Mental Health. doi:10.1080/1360 7863.2019.1633620

Garner, R. (2003). Political ideologies and the moral status of animals. Journal of Political Ideologies, 8(2), 233-246.

Gee, N. R., Mueller, M. K., \& Curl, A. L. (2017). Humananimal interaction and older adults: An overview. Frontiers in Psychology, 8. https://doi.org/10.3389/ fpsyg.2017.01416

Geist, T. (2011). Conceptual framework for animal-assisted therapy. Child \& Adolescent Social Work, 28, 243-256.

Glenk, L. M. (2017). Current perspectives on therapy dog welfare in animal-assisted interventions. Animals, 7(2), 7. doi:10.3390/ani7020007 
Green, P. C., \& Gullone, E. (2005). Knowledge and attitude of Australian veterinarians to animal abuse and human interpersonal violence. Australian Veterinary Journal, 83(10), 619-625.

Hanrahan, C. (2011). Challenging anthropocentricism in social work through ethics and spirituality: Lessons from studies in human-animal bonds. Journal of Religion \& Spirituality in Social Work: Social Thought, 30, 272-293.

Hanrahan, C. (2013). Social work and human animal bonds and benefits in health research: A provincial study. Critical Social Work, 14(1), 63-79.

Hatch, A. (2007). The view from all fours: A look at an animal-assisted activity program from the animals perspective. Anthrozoos, 20, 37-50.

Hodgson, K., \& Darling, M. (2011). Zooeyia: An essential component of "One Health". The Canadian Veterinary Journal, 52(2), 189-191.

Holcombe, T. M., Strand, E. B., Nugent, W. R., \& Ng, Z. Y. (2016). Veterinary social work: Practice within veterinary settings. Journal of Human Behavior in the Social Environment, 26(1), 69-80.

Howie, A. R. (2015). Teaming with your therapy dog: New directions in the human-animal bond. Purdue University Press.

Humphrey, B. (2002). Child welfare, animal welfare Strengthening the links. Social Work Now, December, 4-9.

Hyers, L. (2015). Myths used to legitimize the exploitation of animals: An application of social dominance theory. Anthrozoos, 19(3), 194-210.

Krause-Parello, C. A., Gulick, E. E., \& Basin, B. (2019). Loneliness, depression, and physical activity in older adults: The therapeutic role of human-animal interactions. Anthrozoos, 32(2), 239-254.

Jackson, K. (2013). The human-animal connection in social work. Social Work Today, 13(2), 6. Retrieved from https:// www.socialworktoday.com/archive/031513p6.shtml

Legge, M. M. (2016). The role of animal-assisted interventions in anti-oppressive social work practice. British Journal of Social Work, 46, 1926-1941.

Legge, M. M., \& Robinson, M. (2017). Animals in indigenous spiritualities: Implications for critical social work. Journal of Indigenous Social Development, 6(1), 1-20.

Lewis, G. B. (2018). Diversity, pay equity, and pay in social work and other professions. Affilia: Journal of Women \& Social Work, 33(3), 286-299.

Lockwood, R., \& Arkow, P. (2016). Animal abuse and interpersonal violence: The cruelty connection and its implications for veterinary pathology. Veterinary Pathology, 53, 910-918.

Long, D., Long, J., \& Kulkarni, S. (2007). Interpersonal violence and animals: Mandated cross-sector reporting. Journal of Sociology \& Social Welfare, XXXIV(3), 147-163.

McBride, E. A., \& Montgomery, D. J. (2018). Animal welfare: A contemporary understanding demands a contemporary approach to behaviour and training. People \& Animals: The International Journal of Research and Practice, 1(1) https://docs.lib.purdue.edu/paij/vol1/iss1/4

New Zealand Companion Animal Council Inc. (2016). Companion animals in New Zealand 2016. Author.
Retrieved from https://www.nzvna.org.nz/site/nzvna/ files/Documents/Companion\%20Animals_in_

New_Zealand_2016_Report_web.pdf

Ng, Z., Albright, J., Fine, A. H., \& Peralta, J. (2015). Ou ethical and moral responsibility: Ensuring the welfare of therapy animals. In A. H. Fine (Eds.), Handbook on animal-assisted therapy: Foundations and guidelines for animal-assisted interventions (4th ed., pp. 357-377). Elsevier.

Ng, Z., Morse, L., Albright, J., Viera, A., \& Souza, M. (2018). Describing the use of animals in animal-assisted intervention research. Journal of Applied Animal Welfare Science, (October 8), 1-13.

O'Brien, G. V. (2003). People with cognitive disabilities: The argument from marginal cases and social work ethics. Social Work, 48(3), 331-337.

O'Haire, M. E., Guerin, N. A., \& Kirkham, A. C. (2015). Animal-assisted intervention for trauma: A systematic literature review. Frontier Psychology. https://doi. org/10.3389/fpsyg.2015.01121

Payne, E., Boot, M., Starling, M., Henshall, C., McLean, A., Bennett, P., \& McGreevy, P. (2015). Evidence of horsemanship and dogmanship and their application in veterinary contexts. The Veterinary Journal, 204, 247-254.

Payne, E., DeAraugo, J., Bennett, P., \& McGreevy, P. (2016) Exploring the existence and potential underpinnings of dog-human and horse-human attachment bonds. Behavioural Processes, 125, 114-121.

Pinillos, R. G., Appleby, M. C., Manteca, X., Scott-Park, F., Smith, C., \& Velarde, A. (2016). One welfare - A platform for improving human and animal welfare. Veterinary Record, 179, 412-413.

Potts, A. (2010). Introduction: Combatting speciesism in psychology and feminism. Feminism \& Psychology, 20(3), 191-301.

Risley-Curtiss, C. (2007). Call to action: Social workers and other animals. The Lathan Letter, 28(2), 10-11.

Risley-Curtiss, C. (2010). Social work practitioners and the human-companion animal bond: A national study. Social Work, 55(1), 38-46.

Risley-Curtiss, C. (2013). Expanding the ecological lens in child welfare practice to include other animals. Journal of Sociology \& Social Welfare, 40(4), 107-130.

Risley-Curtiss, C., Holley, L. C., \& Kodeine, S. (2011). "They're there for you": Men's relationships with companion animals. Families in Society: The Journal of Contemporary Social Services, 92(4), 1-7.

Risley-Curtiss, C., Holley, L. C., \& Wolf, S. (2006). The animal-human bond and ethnic diversity. Social Work, 51, 257-268.

Risley-Curtiss, C., Rogge, M. E., \& Kawam, E. (2013) Factors affecting social workers' inclusion of animals in practice. Social Work, 58(2), 153-161.

Risley-Curtiss, C., Zilney, L. A., \& Hornung, R. (2010). Animal-human relationships in child protective services: Getting a baseline. Child Welfare, 89(4), 67-82.

Robertson, I. A. (2010). Legally protecting and compelling veterinarians in issues of animal abuse and domestic violence. New Zealand Veterinary Journal, 58, 114-120. 
Roguksi, M. (2012). Pets as pawns: The co-existence of animal cruelty and family violence. Retrieved from http:// nationallinkcoalition.org/wp-content/uploads/2013/01/ DV-PetsAsPawnsNZ.pdf

Ryan, T. (2011). Animals and social work: A moral introduction. Palgrave Macmillan.

Sable, P. (1995). Pets, attachment, and well-being across the life cycle. Social Work, 40, 334-341.

Schlote, S. M. (2002). Animal-assisted therapy and equineassisted therapy/learning in Canada: Surveying the current state of the field, its practitioners, and its practices (Unpublished Masters thesis), The University of Western Ontario, Canada. Retrieved from https:// equusoma.com/wp-content/uploads/2017/06/UVicMasters-Thesis-2009.pdf

Schuck, S. E. B., Johnson, H. L., Abdullah, M. M., Stehli, A., Fine, A. H., \& Lakes, K. D. (2018). The role of animal-assisted intervention on improving selfesteem in children with attention deficit/hyperactivity disorder. Frontiers in Pediatrics, 6. doi.org/10.3389/ fped.2018.00300

Sharpe, M. S., \& Wittum, T. E. (1999). Veterinarian involvement in the prevention and intervention of human violence and animal abuse: A survey of small animal practitioners. Anthrozoos, 12, 97-104.

SPCA. (n.d.). Animal cruelty information for social workers. https://anzasw.nz/wp-content/uploads/SPCA-AnimalCruelty-Information-for-Social-Workers.pdf

Solot, D. (1997). Untangling the animal abuse web. Society \& Animals, 5(3), 257-265.

Strand, E. B., \& Risley-Curtiss, C. (2013). The human-animal bond. In M. P. Brewster, \& C. Reyes (Eds.), Animal cruelty: A multidisciplinary approach to understanding (pp. 81-107). Carolina Academic Press.

Strand, E. B., Poe, B. A., Lyall, S., Yorke, J., Nimer, J., Allen, E., ... Nolen-Pratt, T. (2012). Veterinary social work practice. In C. Dulmus \& K. Sowers (Eds), Social work: Fields of practice (pp. 245-271). John Wiley \& Sons. Taylor, N., \& Fraser, H. (2017). In good company: Women, companion animals, and social work. Society \& Animals, 25(4), 341-361.

Taylor, N., Fraser, H., Signal, T., \& Prentice, K. (2016). Social work, animal-assisted therapies and ethical considerations: A programme example from Central Queensland, Australia. British Journal of Social Work, 46, 135-152.

Tedeschi, P., Fitchett, J., \& Molidor, C. E. (2006). The incorporation of animal-assisted interventions in social work education. Journal of Family Social Work, 9(4), 59-77.

Thompson, K. L., \& Gullone, E. (2006). An investigation into association between the witnessing of animal abuse and adolescents' behaviour toward animals. Society \& Animals, 14(3), 221-244.

Trembath, F. (2014). Practitioner attitudes and beliefs regarding the role animals play in human health. HABRI Central Briefs. Retrieved from https://pdfs. semanticscholar.org/5a35/4333ecdeac86e82bfb8c4b20 5e555797556c.pdf

Uglow, L. S. (2019). The benefits of an animal-assisted intervention service to patients and staff at a children's hospital. British Journal of Nursing, 28(8), 509-515.
VanFleet, R. \& Faa-Thompson, T. (2017). Animal assisted play therapy. Sarasota, FL: Professional Resource Press.

Walker, P., Aimers, J., \& Perry, C. (2015). Animals and social work: An emerging field of practice for Aotearoa New Zealand. Aotearoa New Zealand Social Work, 27(1\&2), 24-25.

Walker, P., \& Tumilty, E. (2019). Developing ethical frameworks in animal-assisted social service delivery in Aotearoa New Zealand. The British Journal of Social Work, 49(1), 163-182.

Walsh, F. (2009). Human-animal bonds I: The relational significance of companion animals. Family Process, 48(4), 462-480.

Watene, K. (2016). Valuing nature: Maori philosophy and the capability approach. Journal of Oxford Development Studies, 44(3), 287-296.

Wells, D. L. (2019). The state of research on human-anima relations: Implications for human health. Anthrozoos, 32(2), 169-181.

Wenocur, K., Cabral, R., \& Karlovits, J. (2018). Social work for all species: Dual consideration of social work ethics and the human-animal bond. Perspectives on Social Work. Retrieved from https://uh-ir.tdl. org/bitstream/handle/10657/5281/Katharine\%20 Wenocur_Rachael\%20Cabral_Jennifer\%20Karlovits\%20 from\%20Perspectives-on-social-work Winter2018. pdf? sequence $=1$ \&isAllowed $=y$

Williams, V. M., Dale, A. R., Clarke, N., \& Garrett, N. K. G. (2008). Animal abuse and family violence: Survey on the recognition of animal abuse by veterinarians in New Zealand and their understanding of the correlation between animal abuse and human violence. New Zealand Veterinary Journal, 56, 21-28.

Wolf, D. B. (2000). Social work and speciesism. Social Work, $45,88-93$

Yeung, P., Mooney, H., English, A., \& O'Donoghue, K. (2020). Non-government organization study awards: Enhancing successful completion of social work qualification. Social Work Education, 39(5), 681-698. 